\section{Fiqih Ibadah}

Konsep Fiqih Ibadah adalah hukum yang bersumber dari syariat Islam yang berkaitan dengan penghambaan diri dalam beribadah kepada Allah SWT. Buku Fiqih Ibadah membahas hukum Allah SWT yang berhubungan dengan amaliah mukallaf yaitu wajib, sunah, mubah, makruh dan haram berdasarkan dalil yang jelas.

Buku ini membahas thaharah dan bagian rukun Islam. Muatan materi pada bagian BAB buku ini mengacu pada kurikulum KKNI pada perguruan tinggi pada umumnya. Buku dapat dipergunakan pada mata kuliah perguruan tinggi Sarjana- 1 . Tujuan adanya buku fiqih ibadah ini sebagai pengangan atau panduan belajar mahasiswa Jam'iyah Mahmudiyah Tanjung Pura dan mahasiswa muslim pada umumnya.

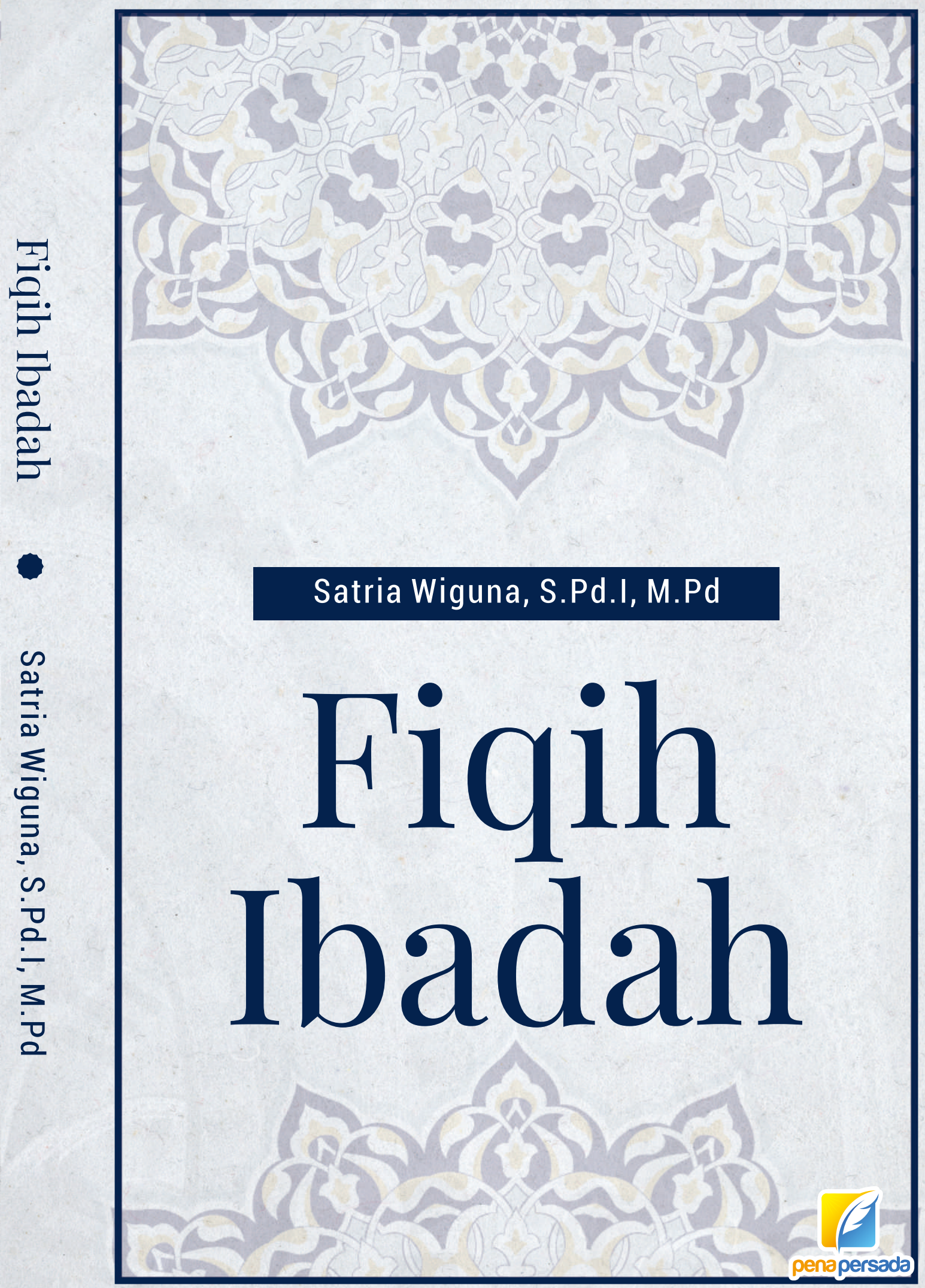




\section{FIQIH IBADAH}

SATRIA WIGUNA, S.Pd.I, M.Pd

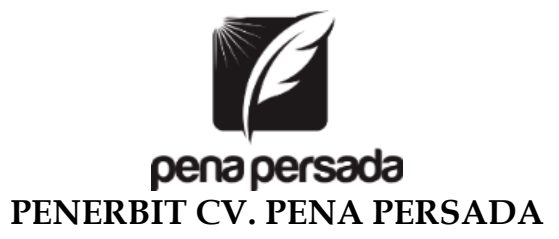




\title{
FIQIH IBADAH
}

\author{
Penulis: \\ Satria Wiguna, S.Pd.I, M.Pd
}

ISBN: 978-623-315-428-4

Design Cover:

Retnani Nur Briliant

\section{Layout:}

Nisa Falahia

\section{Penerbit CV. Pena Persada \\ Redaksi:}

Jl. Gerilya No. 292 Purwokerto Selatan, Kab. Banyumas

Jawa Tengah

Email: penerbit.penapersada@gmail.com

Website: penapersada.com Phone: (0281) 7771388

Anggota IKAPI

All right reserved

Cetakan pertama: 2021

Hak Cipta dilindungi oleh undang-undang. Dilarang memperbanyak karya tulis ini dalam bentuk apapun tanpa izin penerbit 


\section{KATA PENGANTAR}

Alhamdulillah, segala puji dan syukur penulis ucapkan atas segala karunia Allah swt. Saat yang sama penulis juga ingin mengucapkan salawat dan salam kepada Rasulllah saw. semoga kita semuanya kelak mendapatkan syafa'at pada hari kemudian.

Buku ini berjudul "Fiqih Ibadah", atas segalanya sudah barang tentu dalam proses penyusunan buku ini membutuhkan banyak dukungan moral maupun moril. Untuk itu, dalam kesempatan ini penulis menyampaikan rasa hormat dan ucapan terimakasih yang sebesarnya, kepada:

1. Kebijakan Perguruan Tinggi STAI Jam'iyah Mahmudiyah Tanjung Pura yang telah membeikan kebijakan dan instruksi bahwa adanya penugasan penyusunan buku yang ber-ISBN dalam rangka penerapan Tri Darma Perguruan tinggi yaitu pendidikan, penelitian dan pengabdian kepada masyarkat. Maka penerbit buku figh Ibadah merupakan hasil karya Ilmiah dibidang pendidikan.

2. Seluruh mahasiswa PRODI PAI-C Jam'iyah Mahmudiyah Tanjung Pura tahun 2021 yang telah bersama menyelesaikan tulisan buku sebagai tugas akhir perkuliahan dengan hasil karya tulis ilmiah bersama yang dapat dibaca dan dipelajari bagi mahasiswa muslim dalam mempelajari Fiqih Ibadah pada kehidupan sehari-hari.

3. Lembaga Penelitian dan pengabdian Masrayakat (LPPM) Jam'iyah Mahmudiyah Tanjung Pura yang telah mereview dan mengkoreksi tulisan naskah buku fiqih ibadah ini.

Kehadiran buku ini adalah salah satu upaya dan usaha dari dosen dan para mahasiswa yang memiliki aspresiasi semangat menulis menjadi suatu hasil karya ilmiah yang berkualitas. Buku ini mengacu pada pembahasan thaharah dan bagian rukun Islam. Muatan materi pada bagian BAB buku ini mengacu pada kurikulum KKNI pada perguruan tinggi pada umumnya. Buku dapat dipergunakan pada mata kuliah perguruan tinggi Sarjana-1. Tujuan adanya buku fiqih ibadah ini sebagai pengangan atau panduan belajar mahasiswa Jam'iyah Mahmudiyah Tanjung Pura 
dan mahasiswa muslim pada umumnya. Buku Fiqih Ibadah membahas hukum Allah SWT yang berhubungan dengasn amaliah mukallaf yaitu wajib, sunah, mubah, makruh dan haram berdasarkan dalil yang jelas.

Penulis menyadari dengan kerendahan hati menyatakan bahwa perlunya perbaikan dan koreksi pada buku ini. Saran dan kritik konstruktif dari semua pihaklah yang akan menjadi bahan penyempurnaannya kelak pada buku ini. Besar harapan pula bagi penulis semoga buku ini dapat memberikan manfaat besar bagi pengembangan pengetahuan hukum Islam.

Tanjung Pura, 24 Mei 2021

Penulis

SATRIA WIGUNA, S.Pd.I, M.Pd 


\section{DAFTAR ISI}

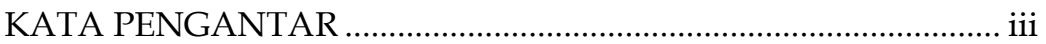

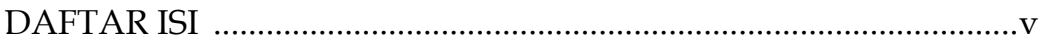

BAB I RUANG LINGKUP FIQIH ..................................................

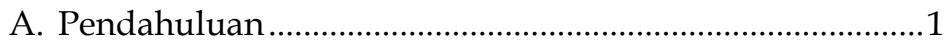

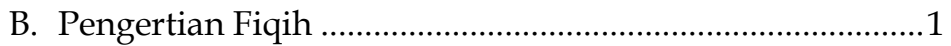

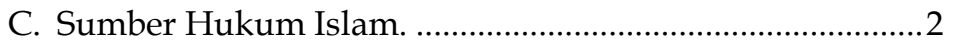

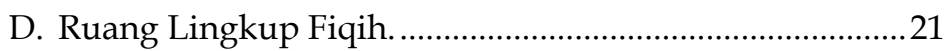

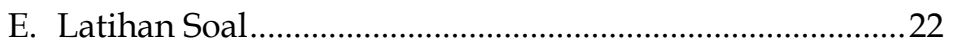

BAB II RUANG LINGKUP FIQIH IBADAH.................................24

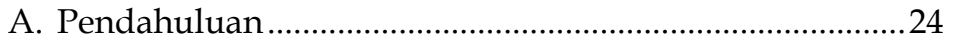

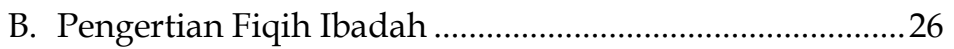

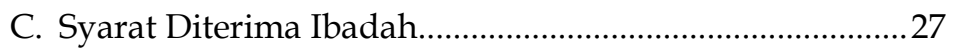

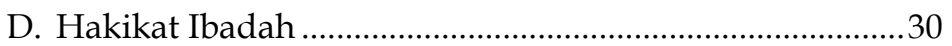

E. Ruang Lingkup dan Sistematika Ibadah.............................31

F. Hubungan Ibadah dengan Iman .........................................32

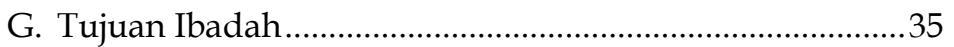

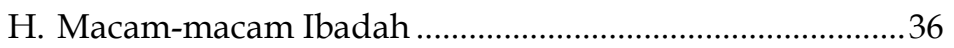

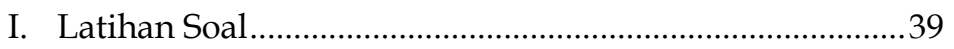

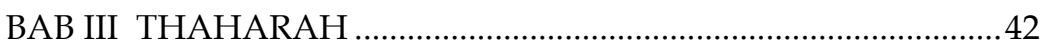

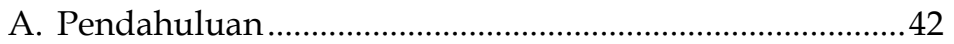

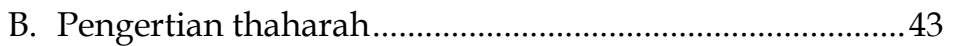

C. Macam - Macam Thaharah...................................................4 44

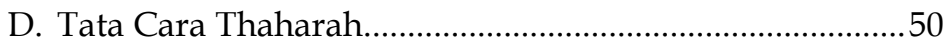

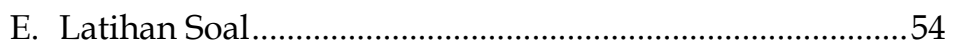

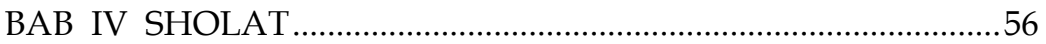

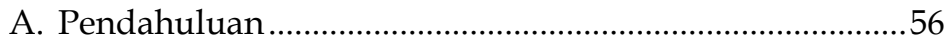

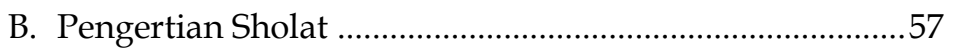

C. Macam-macam Sholat .............................................................58

D. Tata Cara Pelaksanaan Sholat......................................................

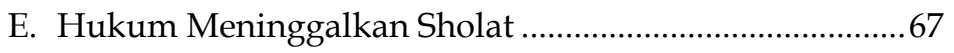

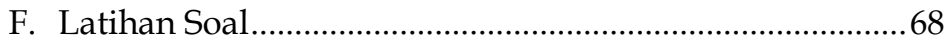

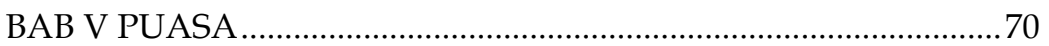

A. Pendahuluan ..................................................................... 70

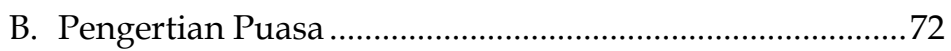




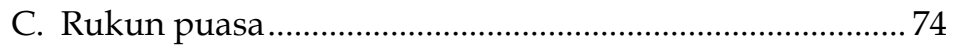

D. Macam-Macam Puasa …………………...................... 76

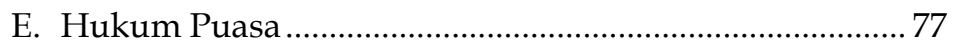

F. Hal-Hal yang Membatalkan Puasa..................................... 79

G. Orang yang diperbolehkan Meninggalkan Puasa............ 82

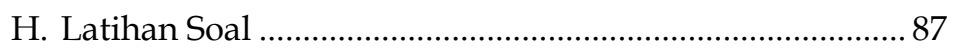

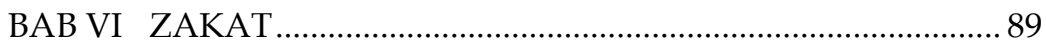

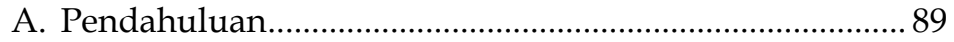

B. Pengertian Zakat ................................................................ 91

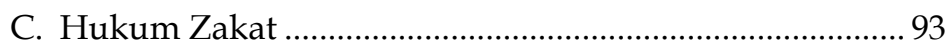

D. Fungsi dan Tujuan Zakat ................................................... 94

E. Syarat Wajib Zakat............................................................... 97

F. Golongan yang Berhak Menerima Zakat........................... 98

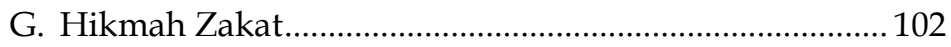

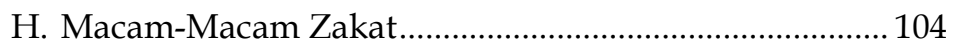

I. LATIHAN SOAL …………........................................ 112

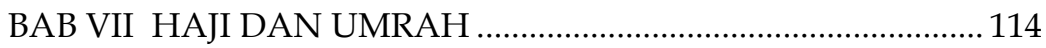

A. Pendahuluan................................................................. 114

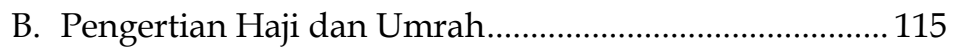

C. Tujuan Haji dan Umrah ................................................ 120

D. Dasar Hukum Perintah Haji dan Umrah......................... 124

E. Syarat, Rukun, Wajib Haji dan Umrah ............................. 125

F. Sunnah, Larangan dan Dam Pada Haji dan Umrah ..... 129

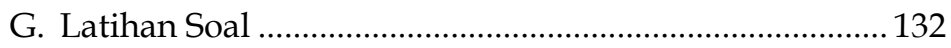

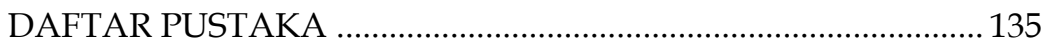

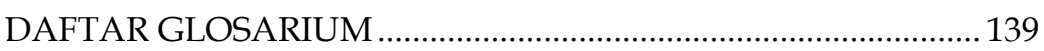

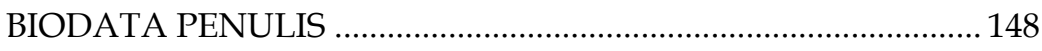




\section{BAB I \\ RUANG LINGKUP FIQIH \\ Oleh: Rifka Bikro, Andi Gunawan dan Ariska Julianti}

\section{A. Pendahuluan}

Fiqih berasal dari kata faqiha-yafqahu-fighan yang bermakna mengerti atau memahami. Fiqih merupakan sebuah ilmu yang mengkaji mengenai hukum-hukum syariat yang bersifat amaliah yang didasarkan pada dalil-dalil yang tafsil kemudian digali atau dikaji melalui penalaran dan istidlal para mujtahid. Fiqih berupa ilmu yang didapati melalui ra'yu (akal) dan ijtihad dengan menggunakan analisis manusia atau para ahli fuqaha. Fiqih adalah bentuk perwujudan hukum yang zanni dan pancaran dari syariat. Tidak hanya itu fiqih juga merujuk pada sumber hukum Islam baik yang muttafaq (disepakati) maupun yang masih diperselisihkan (mukhtalaf) sebagai sumber hukum Islam, yaitu, seperti istihsan, maslahah mursalah, urf, istishab, sadduz-dzari'ah, syar'u man qablana, dan qaulusshahabi.

Ruang lingkup fiqih tidak hanya merujuk pada sumber hukum Islam saja tetapi juga mengenai tata cara beribadah kepada Allah, menjelaskan tentang muamalat (hubungan sesama manusia), hukum kekeluargaan, bahkan hukum mengenai pelaku jinayat.

\section{B. Pengertian Fiqih}

Kata fiqih dalam bahasa arab berasal dari kata faqihayafqahu-fighan yang bermakna mengerti atau memahami. (Syafiq Gharbal, 1965: 1304). Secara terminologi fiqih berarti ilmu tentang hukum-hukum syar'i yang bersifat amaliah yang digali dan ditemukan dari dalil-dalil yang tafsil.

Berdasarkan definisi ini, fiqih diibaratkan ilmu karena fiqih itu semacam ilmu pengetahuan. Memang fiqih itu tidak sama dengan ilmu seperti disebutkan di atas, fiqih itu bersifat zhanni. Fiqih adalah apa yang dapat dicapai oleh mujtahid 
dengan zhan-nya, sedangkan ilmu tidak bersifat zhanni seperti fiqh. Namun karena zhan dalam fiqih ini kuat, maka ia mendekati kepada ilmu karena dalam definisi ini ilmu digunakan juga untuk fiqih (Amir Syarifuddin, 1997: 3). Fiqh menurut penulis dapat didefinisikan sebagai ilmu mengenai hukum-hukum syar'i yang bersifat amaliah yang didasarkan pada dalil-dalil yang tafsil kemudian digali atau dikaji melalui penalaran dan istidlal para mujtahid.

Fiqih merupakan ilmu yang diperoleh melalui ra'yu dan ijtihad dengan menggunakan penyelidikan manusia. Oleh sebab itu, fiqih tidak sama dengan syariat karena fiqih berupa hasil pemikiran manusia, sedangkan syariat adalah wahyu yang datangnya dari Allah SWT dan sunnah Nabi Muhammad Saw. Fiqih adalah bentuk perwujudan hukum yang zanni dan pancaran dari syariat. Tidak hanya itu fiqih juga merujuk pada hukum-hukum yang masih diperselisihkan sebagai sumber hukum Islam, yaitu, istihsan, istishab, maslahah mursalah, urf, dan lain sebagainya.

Berdasarkan hal tersebut, dapat disimpulkan bahwa pada hakikatnya fiqih dapat dipahami dari empat sudut pandang:

1. Fiqih yaitu ilmu mengenai syara'

2. Fiqih menganalisis hal-hal yang bersifat amaliah furu'iyah (praktis dan bersifat cabang).

3. Pengetahuan tentang hukum syara' yang didasarkan pada dalil tafsil yaitu Al-Qur'an dan sunnah.

4. Fiqih digali dan ditentukan melalui penalaran dan istidlal (penarikan kesimpulan) mujtahid.

\section{Sumber Hukum Islam.}

Sumber hukum islam dapat diklasifikasikan menjadi dua golongan yaitu sumber hukum Islam yang muttafaq (disepakati) dan sumber hukum Islam yang mukhtalaf (diperselisihkan). Sumber hukum Islam yang muttafaq di antaranya Al-Qur'an, hadis, ijma dan qiyas. Sumber hukum islam yang mukhtalaf seperti istihsan, maslahah mursalah, urf, istishab, sadduz-dzari'ah, syar'u man qablana, dan qaulusshahabi. 


\section{Sumber Hukum Islam Yang Muttafaq (disepakati), sebagai berikut:}

1. Al-Qur'an.

Berdasarkan segi bahasa, Al-Qur'ān berasal dari kata qara'a-yaqra'u-qira'atan-qur'anan, yang berarti sesuatu yang dibaca atau bacaan. Dari segi istilah, Al-Qur'an adalah Kalamullah yang diturunkan kepada Nabi Muhammad saw. dalam bahasa Arab, yang sampai kepada kita secara mutawattir, ditulis dalam mushaf, dimulai dengan surah alFātihah dan diakhiri dengan surah an-Nas, membacanya berfungsi sebagai ibadah, sebagai mukjizat Nabi Muhammad saw. dan sebagai hidayah atau petunjuk bagi umat manusia (Intan Suliyostari, 2004: 47-48). Sebagiaman Allah SWT menjelaskan dengan firman, sebagai berikut:

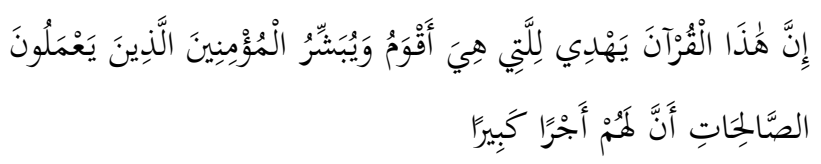

Artinya: "Sungguh, Al-Qur'an ini memberi petunjuk ke (jalan) yang paling lurus dan memberi kabar gembira kepada orang mukmin yang mengerjakan kebajikan, bahwa mereka akan mendapat pahala yang besar." (Q.S. alIsrā/17:9).

Al-Qur'an merupakan kitab suci utama dalam agama Islam yang diturunkan oleh Allah swt. kepada Nabi Muhammad saw sebagai sumber hukum islam yang pertama, sekaligus sebagai mukjizat pagi nabi muhammad dan salah satu tanda kenabian nya. Al-Qur'an terdiri dari 30 Juz, 114 surat, 6.236 ayat, 323.015 huruf dan 77.439 kosa kata. Al-Qur'an diturunkan secara Mutawatir berangsurangsur selama 22 tahun 2 bulan dan 22 hari atau setara dengan 23 tahun. 
Penurunan Al-Qur'an sebagai sumber hukum Islam yang kedua terbagi menjadi dua periode yaitu periode Makkah dan periode Madinah. Periode madinah berlangsung selama 12 tahun pada masa kenabian nabi Muhammad dan termasuk ke dalam golongan surah Makiyyah, dan pada periode Madinah dimulai sejak peristiwa hijrah Nabi berlangsung selama 10 tahun dan termasuk ke dalam golongan surah Madaniyah.

Isi pokok kandungan Al-Qur'an (ditinjau dari segi hukum) terbagi menjadi tiga bagian, diantaranya:

a. Akidah atau Keimanan yaitu keyakinan yang tertancap kuat di dalam hati. Akidah terkait dengan keimanan terhadap hal-hal yang gaib yang terangkum dalam rukun iman (arkānu mān). Hukum yang mengatur hubungan rohaniah dengan Allah swt. dan hal - hal lain yang berkaitan dengan keimanan. Ilmu yang mempelajarinya disebut Ilmu Tauhid atau Ilmu Kalam.

b. Syari'ah atau Ibadah yaitu hukum ini mengatur tentang tata cara ibadah baik yang berhubungan langsung dengan al-Khaliq (Pencipta) yaitu Allah swt. yang disebut ibadah mahdah, maupun yang berhubungan dengan sesama makhluknya yang disebut dengan ibadah ghairu mahdah. Ilmu yang mempelajari tata cara ibadah dinamakan ilmu fikih.

1) Hukum Ibadah, hukum ini mengatur bagaimana seharusnya melaksanakan ibadah yang sesuai dengan ajaran Islam. Hukum ini mengandung perintah untuk mengerjakan salat, haji, zakat, puasa, dan lain sebagainya.

2) Hukum Mu'amalah, hukum ini mengatur interaksi antara manusia dan sesamanya, seperti hukum tentang tata cara jual-beli, hukum pidana, hukum perdata, hukum warisan, pernikahan, politik, dan lain sebagainya. 
c. Akhlak atau Budi Pekerti yaitu Al-Qur'an menuntun bagaimana seharusnya manusia berakhlak atau berperilaku baik berakhlak kepada Allah swt, kepada sesama manusia, akhlak terhadap makhluk Allah Swt atau yang lain, dan hubungan manusia dengan alam semesta. Hukum ini tecermin dalam konsep perbuatan manusia yang tampak, mulai dari gerakan mulut (ucapan), tangan, dan kaki.

Berdasarkan uraian di atas Al-Qur'an dapat disimpulkan sebagai berikut: Al-Qur'an merupakan Kalamullah yang diturunkan kepada Nabi Muhammad melalui perantara malaikat Jibril dan sebagai salah satu mukjizat dan tanda kenabian Nabi Muhammad saw, AlQur'an sebagai sumber hukum islam pertama. Isi pokok kandungan Al-Qur'an yaitu menjelaskan dan mengatur mengenai hukum aqidah dan keimanan, syariah atau ibadah serta akhlak maupun budi pekerti.

2. Hadits

Hadits merupakan segala tingkah laku Nabi Muhammad saw. baik dari segi perkataan, perbuatan, maupun ketetapan (taqrir). Hadits merupakan sumber hukum Islam yang kedua setelah Al-Qur'an. Allah SWT telah mewajibkan untuk menaati hukum-hukum dan perbuatan-perbuatan yang disampaikan oleh nabi Muhammad saw. dalam haditsnya (Departemen Agama RI, 2010: 906). Hal ini sejalan dengan firman Allah swt:

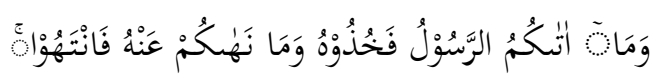

Artinya: "Apa yang diberikan Rasul kepadamu maka terimalah dia, dan apa yang dilarangnya bagimu maka tinggalkanlah, ..." (QS Al Hashr : 7). 
Perintah meneladani Rasulullah saw. ini disebabkan seluruh perilaku Nabi Muhammad saw. mengandung nilainilai luhur dan merupakan cerminan akhlak mulia. Apabila seseorang bisa meneladaninya maka akan mulia pula sikap dan perbuatannya. Hal tersebut dikarenakan Rasulullah saw. memiliki akhlak dan budi pekerti yang sangat mulia.

Hadits merupakan sumber hukum Islam yang kedua memiliki kedua fungsi sebagai berikut.

a. Memperkuat hukum-hukum yang telah ditentukan oleh Al-Qur'an, sehingga keduanya (Al-Qur'an dan Hadits) menjadi sumber hukum untuk satu hal yang sama.

b. Memberikan rincian dan penjelasan terhadap ayat-ayat Al-Qur'an yang masih bersifat umum. Misalnya, ayat AlQur'an yang memerintahkan shalat, membayar zakat, dan menunaikan ibadah haji, semuanya bersifat garis besar. Seperti tidak menjelaskan jumlah rakaat dan bagaimana cara melaksanakan shalat, tidak merinci batas mulai wajib zakat, tidak memarkan cara-cara melaksanakan haji. Rincian semua itu telah dijelaskan oleh Rasullah saw. dalam haditsnya. Contoh lain, dalam Al-Qur'an Allah swt. mengharamkan bangkai, darah dan daging babi. Firman Allah sebagai berikut :

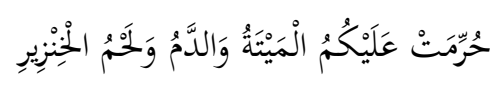

Artinya: "Diharamkan bagimu bangkai, darah, dan daging babi.." (QS Al Maidah : 3)

3. Ijma'

Secara etimologi ijma' berarti kebulatan tekad terhadap suatu persoalan atau kesepakatan tentang suatu masalah" (Nurhayati, 2018: 28). Menurut istilah ushul fiqh ijma' adalah berupa kesepakatan seluruh mujtahid di kalangan umat Islam pada suatu masa setelah Rasulullah saw. wafat dan kesepakatan tersebut mengenai suatu hukum syara terhadap suatu kejadian atau permasalahan. 
Para ulama sepakat mengatakan bahwa ijma' sebagai sumber hukum Islam ketiga setelah Al-Qur'an dan Hadis.

Ijma' dari segi kualitasnya terdapat dua jenis yaitu ijma' sharih dan ijma' sukuti:

a. Ijma' Sharih yakni secara etimologi sharih mempunyai arti jelas. Ijma' sharih merupakan ijma' yang memaparkan banyak pendapat ulama secara jelas dan terbuka, baik dengan ucapan maupun perbuatan. Ijma' sharih ini menempati tingkatan ijma' tertinggi. Para ulama sepakat hukum yang ditetapkan dalam ijma' sharih ini bersifat qath'i, sehingga umat wajib mengikutinya" (Zuhri, 1994: 32). Oleh karena itu seluruh ulama sepakat dan bersedia untuk menjadikan ijma' sharih sebagai dalil yang sah dan kuat dalam penetapan hukum syariat Islam.

b. Ijma' Sukuti

Sukuti secara bahasa berarti diam. Sebuah ijma' disebut sebagai ijma' sukuti apabila sebagian mujtahid memberikan pendapat-pendapatnya secara terang dan jelas mengenai suatu hukum atau peristiwa melalui perkataan maupun perbuatan, sedangkan mujtahid yang lain tidak memberikan pendapat apakah dia menerima atau menolak.

Ijma' sukuti ini bersifat dzanni dan tidak memikat dan hukumnya masih diragukan. Sehingga tidak ada halangan bagi para mujtahid untuk memaparkan pendapat yang berbeda setelah ijma' itu diputuskan. Imam Syafi'I dan Imam Maliki berpendapat bahwa ijma' sukuti tidak dapat dijadikan dasar hukum. Namun Imam Abu Hanifah dan Imam Ahmad bin Hanbal berpendapat lain yaitu menjadikan ijma' sukuti sebagai dasar hukum. Mereka menerima ijma' sukuti sebagai hujjah karena menurutnya kedua Imam tersebut diamnya mujtahid dianggap sebagai tanda setuju. 
Terdapat perbedaan pendapat di kalangan para ulama mengenai ijma' apakah dapat dipandang sebagai dalil syara atau tidak. Namun Jumhur ulama ushul fiqh mengatakan bahwa ijma' sebagai upaya ijtihad para mujtahid dalam menetapkan hukum suatu permasalahan yang tidak ada hukumnya dalam nash dan harus mempunyai landasan.

Jumhur ulama berpendapat bahwa ijma' merupakan salah satu sumber atau dalil hukum yang telah disepakati setelah Al-Qur'an dan As-Sunnah. Ijma' dapat menetapkan hukum yang tidak ada ketetapan hukumnya di dalam Al-Qur'an maupun sunnah, hukum ijma' tersebut bersifat mengikat dan wajib dipatuhi umat Islam. Kesepakatan jumhur ulama ini berdasarkan Q.S an-Nisa ayat 115. “Dan barang siapa yang menentang Rasul sesudah jelas kebenaran baginya, dan mengikuti jalan yang bukan jalan orang-orang mukmin, kami biarkan ia leluasa terhadap kesesatan yang Telah dikuasainya itu dan kami masukkan ia ke dalam Jahannam, dan Jahannam itu seburuk-buruk tempat kembali" (QS.an-Nisa: 115)

Ayat ini sapat dipahami wajib hukumnya mengikuti jalan-jalan orang mukmin yaitu dengan mengikuti kesepakatan mereka. Ijma' baru bisa diakui sebagai landasan hukum Islam jika pembentukannya mempunyai landasan syara atau sanad ijma'. Dan ulama ushul fiqh sepakat bahwa Al-Qur'an dan sunnah sebagai landasan ijma'.

4. Qiyas

Qiyas (analogi) adalah menghubungkan suatu kejadian yang tidak ada hukumnya dengan kejadian lain yang sudah ada hukumnya karena antara keduanya terdapat persamaan illat atau sebab-sebabnya. Contohnya, mengharamkan minuman keras, seperti bir dan wiski. Haramnya minuman keras ini diqiyaskan dengan khamar 
yang disebut dalam Al Qur"an karena antara keduanya terdapat persamaan illat (alasan), yaitu sama-sama memabukkan. Jadi, walaupun bir tidak ada ketetapan hukumnya dalam Al-Qur'an atau hadits tetap diharamkan karena mengandung persamaan dengan khamar yang ada hukumnya dalam Al-Qur'an. Qiyas merupakan sumber hukum Islam yang keempat dan muttafaq (disepakati).

Sebelum mengambil keputusan dengan menggunakan qiyas maka ada baiknya mengetahui Rukun Qiyas, yaitu:
a. Dasar (dalil)
b. Masalah yang akan diqiyaskan
c. Hukum yang terdapat pada dalil
d. Kesamaan sebab/alasan antara dalil dan masalah yang diqiyaskan.

\section{Sumber Hukum Islam yang Mukhtalaf (diperselisihkan)}

1. Istihsan

Istihsan ( استحسان) secara etimologi (lughawi/bahasa) memiliki makna "memperhitungkan sesuatu lebih baik", atau "adanya sesuatu itu lebih baik", atau "mengikuti sesuatu yang lebih baik", dan atau "mencari yang lebih baik untuk diikuti, karena memang disuruh untuk itu". Secara terminologi istihsan merupakan perpindahan seorang mujtahid dari ketentuan qiyas yang jelas (jali) kepada ketentuan qiyas yang samar (khafi), atau dari ketentuan yang umum (kulli) kepada ke ketentuan yang bersifat khusus.

Istihsan merupakan salah satu langkah atau metode ijtihad yang diperselisihkan (mukhtalaf) oleh para ulama, walaupun pada kenyataannya semua ulama menggunakannya secara praktis. Terjadinya perselisihan terhadap penggunaan istihsan dikarenakan adanya perbedaan pendapat dalam memahami dan mendefinisikan istihsan. Ulama yang menggunakan metode istihsan dalam 
berijtihad mengartikan istihsan dengan pengertian yang berlainan dengan definisi ulama yang menolak cara istihsan. Begitu juga sebaliknya, ulama yang menolak penggunaan istihsan mengartikan istihsan dengan pengertian yang berbeda dengan definisi istihsan dari ulama yang menggunakannya.

Mereka berbeda di dalam memformulasikan katakatanya, tetapi mereka sepakat bahwa pengertian Istihsan ialah perpindahan dari suatu hukum kepada hukum lainnya dalam sebagian kasus atau meninggalkan suatu hukum, karena adanya hukum lain yang lebih kuat atau pengecualian yang bersifat Juz'iyyah dari hukum yang Kulliyah atau mengkhususkan sesuatu hukum yang umum dengan hukum yang khusus. Mereka sepakat pula bahwa perpindahan ini harus ada sandarannya yaitu yang berupa Dalil Syara yakni berupa Nash atau Ma'qul-nya Nash atau Mashlahat atau Urf yang shahih. Dalil-dalil sandaran ini disebut Wajh al-Istihsan atau Sanad al-Istihsan (Kedenan, 2018: 94).

Sebagian ulama lainnya mengatakan bahwa definisi istihsan merupakan perbuatan adil dalam hukum yang menggunakan dalil adat untuk kemaslahatan manusia. Dan masih banyak lagi pendapat ulama lainnya mengenai istihsan ini. Seandainya saja para ulama bersepakat dalam mendefinisikan istihsan maka kemungkinan besar mereka tidak akan berbeda pendapat dalam menggunakan istihsan sebagai suatu metode ijtihad. Adapun kehujjahan istihsan ini menurut ulama sebagai berikut:

a. Ulama Hanafiyah, Abu Hanifah banyak menggunakan istihsan dan mengakui adanya istihsan. Hal ini terdapat dalam keterangan yang ditulis dalam beberapa kita ushul dan dalam beberapa kita fiqhnya banyak sekali terdapat permasalahan yang menyangkut istihsan.

b. Ulama Malikiyah, Asy-Syatibi berkata bahwa istihsan itu dianggap dalil yang kuat dalam menetapkan hukum seperti pendapat imam Maliki dan imam Abu Hanifah 
dan begitu pula menurut pandangan Abu Zahrah, bahwa imam Malik berfatwa dengan menggunakan istihsan.

c. Ulama Hanabilah, disebutkan dalam beberapa kitab ushul bahwa golongan Hanabilah mengakui adanya ihtihsan. Tetapi, Al-Jalalal-Mahalli dalam kitabnya Al Jam' Al-Jawami' mengatakan bahwa istihsan itu memang diakui oleh Abu Hanifah namun ada juga ulama yang lain mengingkari adanya istihsan termasuk di antaranya golongan Hanabilah.

d. Ulama Syafi'iyah, secara masyhur tidak mengakui adanya istihsan, dan mereka benar-benar menjauhi untuk menggunakan istihsan dalam istinbat hukum dan tidak menggunakannya sebagai dalil. Imam Syafi'i juga berkata "Barang siapa menggunakan istihsan berarti ia telah membuat syari'at".

Ulama-ulama yang menolak Istihsan sebagai dalil syara', mereka beralasan apabila Istihsan dibolehkan dalam berijtihad yang tidak berdasarkan dengan Nash atau tidak dikembalikan kepada Nash, maka Istihsan boleh dilakukan oleh siapa saja meskipun tidak mengetahui Al-Qur'an. Atas dasar alasan-alasan ini, maka Imam asy-Syafi'i berkesimpulan bahwa: "Man Istahsana Faqad Syara" artinya: "Barang siapa yang menetapkan hukum dengan Istihsan berarti dia telah membuat syari'at sendiri".

Para ulama yang menerima Istihsan sebagai dalil hukum, mereka mengembalikan dasar Istihsan kepada AlQur'an dan as-Sunnah. Adapun dalil yang berasal dari AlQur'an antara lain yaitu:

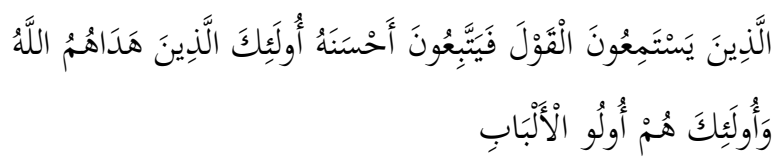


Artinya: “...sebab itu sampaikanlah kabar gembira itu kepada hamba-hamba-Ku, (yaitu) mereka yang mendengarkan perkataan lalu mengikuti apa yang paling baik di antaranya. Mereka itulah orang-orang yang telah diberi petunjuk oleh Allah dan mereka itulah orang-orang yang mempunyai akal sehat." (az-Zumar: 1718).

\section{Maslahah Mursalah}

Maslahah secara harfiah berarti manfaat dan mursalah berarti netral. Sebagai istilah hukum Islam, maslahah mursalah dimaksudkan sebagai segala kepentingan yang bermanfaat dan baik, namun tidak ada nash khusus (teks Al-Qur'an dan Hadits Nabi saw.) yang mendukungnya secara langsung ataupun yang melarangnya. Dengan kata lain, maslahah mursalah adalah segala kepentingan yang baik yang tidak dilarang oleh AlQur'an dan Hadits Nabi saw. dan juga tidak terdapat penegasannya di dalam kedua sumber itu secara langsung. Apabila suatu kepentingan yang baik ditegaskan secara langsung dalam Al-Qur'an dan Hadits disebut maslahah $m u^{\prime}$ tabarah, dan apabila suatu yang menurut anggapan kita baik dan bermanfaat tetapi ternyata dilarang dalam kedua sumber tekstual itu, maka itu disebut maslahah mulgah (batal). Sementara itu, maslahah muralah bersifat netral dalam arti tidak ada larangannya dalam Al-Qur'an dan Hadits, tetapi juga tidak ada pembenarannya secara langsung.

Contohnya adalah melakukan pencatatan nikah. Di dalam Al-Qur'an dan Hadits tidak ada perintah langsung agar mencatatkan pernikahan. Bahkan di zaman Nabi saw. dan beberapa abad lamanya sepeninggal beliau umat Islam tidak mencatat nikahnya. Namun demikian, tidak ada larangan mencatatkannya. Justru dengan mencatatkan nikah itu akan terwujud suatu kebaikan dan kemanfaatan yang besar dan masyarakat terhindar dari kemudharatan. Atas 
dasar kebaikan dan manfaat dari pencatatan nikah itu, maka beberapa ijtihad hukum Islam modern menetapkan kewajiban mencatatkan nikah. Ketentuan hukum seperti ini didasari oleh maslahah mursalah.

3. Urf

Adat atau urf dalam istilah hukum Islam adalah suatu hal yang diakui keberadaannya dan diikuti oleh dan menjadi kebiasaan dalam masyarakat, baik berupa perkataan maupun perbuatan, sepanjang tidak bertentangan denga ketentuan nash syariah atau ijma'. Adapun yang mendefinisikan sebagai suatu kebiasaan masyarakat yang diakui oleh jiwa kolektif dan diterima oleh akal sehat, baik berupa perkataan ataupun perbuatan sejauh tidak bertentangan dengan nash atau ijma' (Ahmad Sudirman Abbas, 2004: 164).

Hukum Islam mengakui adat istiadat masyarakat sebagai sumber hukum, akan tetapi dengan beberapa syarat, yaitu: adat tersebut tidak bertentangan dengan nash (AlQur'an dan Hadits) atau ijma' dan adat itu konstan dan berlaku umum di dalam masyarakat.

\section{Istishab}

Istishab menurut bahasa berasal dari kata istishaba bermakna istif'al atau istimrar as-sahabat yang berarti membandingkan sesuatu dan mendekatkannya atau adanya hubungan atau mencari sesuatu yang ada hubungannya.

Terdapat beberapa definisi yang dikemukakan oleh para ulama ushul fiqh mengenai istishab, antara lain: AlAsnawi (w. $772 \mathrm{H}$ ), menyatakan bahwa istishab adalah penetapan (keberlakuan) hukum terhadap suatu perkara di masa selanjutnya atas dasar bahwa hukum itu telah berlaku sebelumnya, karena tidak adanya suatu hal yang mengharuskan terjadinya perubahan (hukum tersebut). AlQarafy (w. $486 \mathrm{H}$ ) menyatakan istishab sebagai keyakinan bahwa keberadaan sesuatu di masa lalu dan sekarang itu 